\title{
Study of the impact of military factors and security threats on construction projects in Baghdad
}

\author{
Andrey Schreiber, Ivan Abramov*, and Zaid Al-Zaidi \\ Moscow State University of Civil Engineering, 129377, Moscow, Russia
}

\begin{abstract}
Since 2003, the territory of Iraq there were many military conflicts and conducted a large number of terrorist operations, especially in the capital Baghdad.As a result, construction work in Baghdad began to increase after 2003, which led to an increase in construction risks. The most dangerous risks were military conflicts that occurred near the construction site and affected the workforce, equipment and the construction site itself. The purpose of the study is to identify the most important factors causing risks during construction in Baghdad due to military operations and terrorist threats, to assess the degree of impact of these factors on the duration, cost and quality of construction work, as well as on the safety of workers and the economic situation of construction enterprises. The object of the study is the Al-Radwaniyah residential complex under construction in Baghdad, which is located near the US military base. In the course of the study, the most important military factors causing risks were identified, and then a questionnaire survey was conducted to determine the degree of impact of these factors among employees of enterprises involved in the construction of the specified residential complex (contractors, engineers, consultants, etc.). After processing the results of the questionnaire, the risk factors were analysed using a statistical method. This made it possible to establish the degree of impact of each factor. The study showed the degree of influence of military factors that cause risks, in particular, on the safety and life of workers, the impact on the psychological and social state of the working staff in general. It was also found that sudden military clashes and terrorist operations in the study region have a negative impact on the economic and financial situation of the construction project, lead to a delay in the project and increase its cost. Therefore, it is necessary to look for solutions to avoid or reduce these factors in areas where there is a possibility of their sudden occurrence.
\end{abstract}

\section{Introduction}

\footnotetext{
*Corresponding author: ivan2193@yandex.ru
} 
The war in Iraq, launched by the United States in 2003, had political and economic motives, due to a strategy aimed at establishing control over all areas of the country, especially the capital Baghdad. The presence of US military forces had a significant impact on the reconstruction and construction of buildings and structures. Military conflicts and terrorist operations are still on going in the country, which hinder the implementation of construction and affect the duration, quality and cost of construction projects. Thus, terrorist threats and military actions are the most significant risks affecting investment and construction projects in the region in general and Baghdad in particular.

Accidents resulting from the risks associated with the construction industry, have an impact on the human factor, which in turn has a major impact on society, in addition to all the material and technical losses, which make the construction industry involves a risk.

Accidents resulting from military and terrorist factors causing risks in the construction industry affect workers, as well as construction materials and equipment that are used in the project [1].

The aim of the study is to identify the military factors causing different risks to which construction production in different parts of Baghdad is exposed from 2003 to the present, as a result of the presence of US military forces and terrorist operations. Since, as a result of military conflicts, the number of injuries among workers at construction sites has increased, cases of damage to machinery, equipment and materials. All this leads to an increase in construction time and cost.

In addition to these factors to be studied, reference should be made to the uncertainty factor that may affect such projects.

Uncertainty usually occurs at the design stage or at the very beginning of the implementation of an investment and construction project, since after all the research and development of all the necessary documentation, during the construction and installation work, the uncertainty is almost zero [2-13].

In the case of construction on a territory where a military conflict occurs, uncertainty arises directly during the construction period. Directly related to the destabilizing factors described in the article, these destabilizing factors and uncertainties associated with the resumption of hostilities or cessation are extremely difficult to predict at the design stage, and therefore the uncertainty in this case increases significantly.

It is also worth noting that in further studies, uncertainty will be taken into account as a coefficient that increases the weight of destabilizing factors. This coefficient will rise based on how tense the military situation is in the region where construction and installation work will be carried out.

Construction production, for the purposes of this work, is understood as a set of production processes performed for the construction (reconstruction) of buildings (including residential buildings), including installation, commissioning and other work inextricably linked to the construction of objects during the preparatory and main construction period, performed by the construction company's own forces and (or) by subcontractors.

The construction enterprise is characterized by: a variety of economic relations; a significant duration of the preparatory and main periods; the need to create a temporary infrastructure; complexity, diversity, individual character and territorial consolidation of the created construction products; material intensity; capital intensity.

$\mathrm{n}$ conditions of uncertainty, decision-making on the organization and management of construction production is subject to risk. Production activity is associated with the risk of deviations from the estimates and calculations, unexpected changes in the situation. Construction production risks are a combination of the likelihood and consequences of adverse events. 
Internal risks are derived from the level of organization and technology of construction production, as well as from technological equipment, labor productivity and represent the risk of losses in the process of work production.

Most of the internal risks are considered manageable, and planning and development of organizational and technical measures are carried out to avoid such risks and / or reduce their negative impact on the results of construction production.

External risks do not depend on the organization of construction production. Their level is influenced by many uncontrollable factors (demographic, geographic, social and climatic). External risks are considered not manageable [3]. To reduce the negative impact of such risks, compensatory measures are developed or the likelihood of such risk events is ignored.

Such military factors that cause external risks outside the control of the parties to the project cannot be foreseen, and therefore the process of managing these risks is very difficult, which affects the entire labor force, machines and materials.

Risk management is a difficult and complex process that requires accurate data. Therefore, the choice of an effective method for assessing risk factors plays an important role at the stages of planning and implementation of investment and construction projects [4-5].

Among the most important consequences of these factors in the construction industry are the reluctance of the labor force to work, as well as the lack of local and international investment enterprises to invest in their projects in such areas.

In order to avoid the listed factors causing risks, it is necessary to ensure the safety of personnel, strictly observe the construction timeframes and save material resources. All this should be the responsibility of the contractors and investors in the project.And must also not forget about the responsibility of the government responsible for the settlement of military conflicts [6].

The assumptions on which this study is based are as follows:

Lack of adequate knowledge about the risks associated with such projects as a result of these factors (military and terrorist threats);

Lack of knowledge of the types of risks to which the project and the parties involved in it may be exposed;

Lack of safety management at enterprises and construction sites;

Lack of necessary elements for safety management in the construction sector within and around the project;

Lack of attention to ensuring the safety of workers at construction sites near military bases;

Lack of statistics of accidents at construction sites for investment enterprises;

The lack of specialized labor for machinery and equipment, and their lack of licenses, ensuring efficiency in the case of the impact of such factors;

\section{Materials and methods}

This study was conducted in the city of Baghdad (Al-Radwaniyah residential complex) due to the geographical location of the facility under construction, it is located near the US military base and Baghdad International Airport. In order to carry out an objective and comprehensive analysis, a survey of specialists from various enterprises related to the construction sector was conducted: state-owned enterprises, private sector enterprises, public and private consulting companies, and contractor companies.

The questionnaire developed in the course of the study involves obtaining all the necessary information about military factors causing risks to determine military risks and terrorist threats, as well as the degree of their danger to the construction project [7-14]. 
The questionnaire is presented in the form of a table, which lists the main military factors. The survey participants were asked to rate the impact and influence of each factor on an investment construction project.

The questionnaire used a Likert scale from 1 to 5 as in Table 1 , this scale is the most widely used in statistical research. The data obtained were analyzed using quantitative statistical methods to rank the listed factors according to their importance, which helped to avoid or reduce their influence.

There are various modifications of the measuring scales, which include from two to seven-point ratings. We used a classical scale consisting of five assessments [8-9]:

Table 1. Risk factor impact matrix

\begin{tabular}{ccccc}
\hline $\begin{array}{c}\text { Ineffective } \\
\text { factor }\end{array}$ & Low factor & Average factor & High factor & Catastrophic factor \\
\hline 1 & 2 & 3 & 4 & 5 \\
\hline
\end{tabular}

The minimum number of experts participating in the study to provide a representative set of statistical data based on the confidence factor of the result $(\mathrm{A}=0.95)$ is determined by the formula (1) [10-11].

$$
E=\frac{c^{2} r_{a} r_{o}}{\Delta^{2}}
$$

where:

$E$ - the minimum required number of experts;

$c$ - confidence coefficient $(0,95)$;

$r_{a}$ - the proportion of sample elements that have this attribute $(0,95)$;

$r_{o}$ - the proportion of sample elements that don't have this attribute $(0,05)$;

$\Delta$ - representatively error $(0,05)$

$$
E=\frac{(0,95)^{2} *(0,95) *(0,05) .}{(0,05)^{2}}=17.2 \sim 18 \text { Per. }
$$

The methodology of the study is to identify the most important military risk factors that affect construction and investment projects in Baghdad. Then, the degree of importance of these factors is measured using a questionnaire and analyzed using a statistical method (arithmetic mean).

$$
\mathrm{A}_{\mathrm{i}}=\frac{\left.\sum \text { (Number of category responses } * \text { Impact of factors } 1 \text { to } 5\right)}{\text { Total number of responses }}
$$

The most important military factors causing various risks that have been identified are collected in Table 2.

Table 2. Weights of importance of military factors

\begin{tabular}{ccc}
\hline Symbol & \multicolumn{1}{c}{ Type of factor } & $\begin{array}{c}\text { Degree of impact of } \\
\text { factors 1 to 5 }\end{array}$ \\
\hline $\mathrm{F}_{1}$ & $\begin{array}{c}\text { Delay in the arrival of construction materials } \\
\text { at the work site due to a sudden blockade of } \\
\text { the road by the military }\end{array}$ & 3.75 \\
\hline $\mathrm{F}_{2}$ & $\begin{array}{c}\text { The inability of workers to reach their jobs } \\
\text { due to curfew as a result of a military attack }\end{array}$ & 4.12 \\
\hline $\mathrm{F}_{3}$ & Workplace injuries caused by indiscriminate \\
gunfire
\end{tabular}


to the possibility of the driver's observation of military bases

\begin{tabular}{|c|c|c|}
\hline $\mathrm{F}_{5}$ & $\begin{array}{l}\text { Sudden takeover of terrorist groups at a } \\
\text { construction site }\end{array}$ & 2.92 \\
\hline $\mathrm{F}_{6}$ & $\begin{array}{c}\text { unscheduled work stoppages due to additional } \\
\text { inspection by military posts of construction } \\
\text { equipment }\end{array}$ & 3.93 \\
\hline $\mathrm{F}_{7}$ & $\begin{array}{l}\text { Significant reduction in the number of } \\
\text { workers due to the dangerous situation on the } \\
\text { construction site }\end{array}$ & 3.34 \\
\hline $\mathrm{F}_{8}$ & $\begin{array}{l}\text { Military convoys entering the jobsite and not } \\
\text { observing warning signs causing confusion in } \\
\text { the work }\end{array}$ & 2.64 \\
\hline $\mathrm{F}_{9}$ & $\begin{array}{l}\text { Damage to the workplace and equipment due } \\
\text { to military clashes }\end{array}$ & 4.36 \\
\hline $\mathrm{F}_{10}$ & $\begin{array}{c}\text { Financial losses to the investor, contractor and } \\
\text { owner due to untimely works and damage to } \\
\text { the object }\end{array}$ & 4.48 \\
\hline $\mathrm{F}_{11}$ & $\begin{array}{l}\text { Interruptions in water and power supply } \\
\text { during military operations }\end{array}$ & 3.19 \\
\hline
\end{tabular}

The considered military factors causing risks are ranked according to the degree of significance, the results are shown in Fig.2.

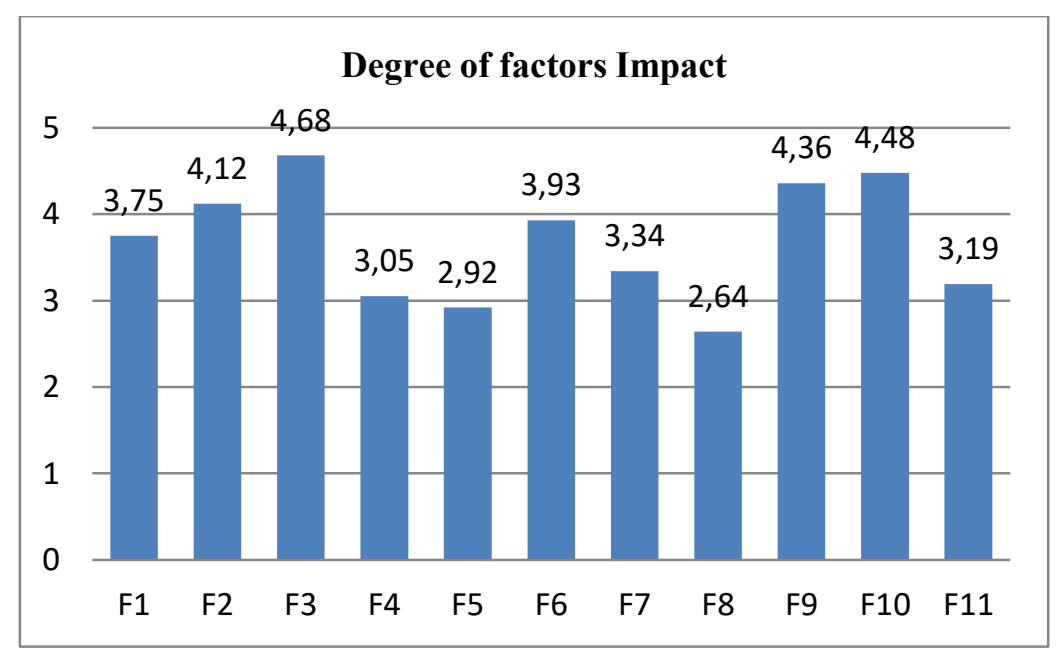

Fig. 2. The degree of significance and impact of military factors

\section{Conclusion}

The study found that military risk factors have a significant impact on construction projects in Baghdad. This influence affects the activities of workers of various professions and the quality of objects under construction, leads to material costs, violation of the deadlines for the implementation of projects. Therefore, construction companies and contractors avoid entering into contracts related to the construction of facilities located close to military bases or territories where military operations are conducted. 
The most dangerous industrial accidents, leading to the death of many workers have been proven to occur during construction work in areas close to the military presence in Baghdad.

Based on the results of the study, the following recommendations were developed:

- For the construction of housing sector and urban infrastructure should be chosen areas located away from military bases;

- It is necessary to eliminate all manifestations of the military presence in the cities and beyond;

- All workers should be familiar with the safety rules and behavior in case of emergencies in the workplace [12-15];

- The Government needs to take active action to eliminate or reduce the number of terrorist groups;

- It is necessary to provide for the conclusion of contracts for the opening of special corridors and roads for the transportation of construction materials and machinery to the place of work;

- Install warning signs in designated areas and maintain constant monitoring of the construction site and the surrounding area to prevent any undesirable situations.

\section{References}

1. K.Yu. Andreev, A.V. Pavlov, The human factor in the system of ensuring the economic security of the Russian Federation in the field of transport infrastructure, Questions of Russian and international law, 10, 170-181 (2015).

2. I.L. Abramov, D.S. Saraeva, Research of systemic principles of organization of construction production in conditions of risks and uncertainty, Science and business: ways of development, 11 (89), 16-21 (2018).

3. I. Abramov, Z. A. K. Al-Zaidi, The Level of Influence of Human and External Risks on a Construction Company's Sustainability (IOP Conf. Ser.: Mater. Sci. Eng.), 753, 042043 (2020).

4. A. Nesticò, S. He, G. De Mare, R. Benintendi, and G. Maselli, The ALARP Principle in the Cost-Benefit Analysis for the Acceptability of Investment Risk, Sustainability, 10, (12), 4668, Dec., doi: 10.3390/su10124668 (2018).

5. A.A. Lapidus, G.B. Safaryan, Quantitative analysis of risk modeling of production and logistics processes in construction, Technology and organization of construction production, 3 (4), 6-9 (2017).

6. Entisar Kadhim Rasheed, Valuation the Impact of Risk on the Goals and the Safety of Construction Projects in Iraq, Journal of Engineering, 21, 1-19 (2015).

7. A.A. Lapidus, I.L. Abramov, Z.A. Al-Zaidi, Application of BIM-technologies to control the assessment of construction risks of the conference, System engineering of construction, cyber-physical building systems, pp. 321-325(2019).

8. I.N. Dubina, Mathematical foundations of empirical socio-economic research: textbook (Publishing house Alt. un-ta, Barnaul, 2006).

9. G.M. Kwon, V.B. Wax, O.G. Pozdeeva, The use of the Likert scale in the study of motivational factors of students, v.11, pp 1039-1052(2018).

10. T.E. Musatova, The methodology for predicting the efficiency of an innovative project based on expert assessments Current problems of science and education (No. 1) (2015). 
11. A.A. Lapidus., I.L. Abramov, Z.A.K. Al-Zaidi, Assessment of the impact of destabilizing factors on implementation of investment and construction projects, IOP Conference Series: Materials Science and Engineering, 951, 012028 (2020) doi:10.1088/1757-899X/951/1/012028.2020.

12. The vendran V. Risk, Management in the construction industry: the relevance of human factors. PhD Thesis, University of Nottingham, Nottingham, UK, 2003.

13. A.A. Lapidus, I.L. Abramov, Sustainability of organizational and production systems in the face of risks and uncertainty in construction production, 6, 8-11 (2018).

14. R. Kazaryan, D. Pogodin, A. Shatrova, Aspects of scheduling processes and results of the reorganization of projects in high-rise construction objects, E3S Web of Conferences, 97, 9, 04002 (2019).

15. A.A. Lapidus, I.L. Abramov, Systemic integrated approach to evaluating the resource potential of a construction company as a bidder, IOP Conference Series: Materials Science and Engineering, 603 (5), 052079 (2019). 